\title{
PERLINDUNGAN HUKUM TERHADAP PEREMPUAN YANG MENGALAMI KEKERASAN DALAM RUMAH TANGGA (KDRT) DI TENGAH PANDEMI COVID-19
}

Oleh:

\author{
Dr. Putu Sekarwangi Saraswati, SH, MH \\ Fakultas Hukum Universitas Mahasaraswati Denpasar, Jalan kamboja Nomor 11A \\ Denpasar
}

\begin{abstract}
The world is currently being faced with a very horrendous event that is a Corona Virus disease. This disease has spread rapidly to all parts of the countries in the world including Indonesia. Because of this Corona Virus, Indonesia has adopted a policy, namely Large-Scale Social Restrictions, this policy has an impact on all sectors of the economy-shial in Indonesia. Because this policy also all Indonesian people do not work and stay at home. This is the main trigger for an act of domestic violence that occurs. Because all people do not work and just stay at home, triggering a dispute that occurs between husband and wife rhich results in an act of violence committed by the husband to his wife. Many factors are the reason why domestic violence occurs, one of which is because of declining economic income or because husbands, wives experience stress because of this condition. Extra efforts are needed to avoid the problem of dosmetic violence that occurs in the pandemic covid-19. One of them by emphasizing the existence of Law Number 23 of 2004.
\end{abstract}

Keyword: legal protection, corona virus, KDRT

\section{ABSTRAK}

Dunia saat ini sedang dihadapi dengan sebuah peristiwa yang sangat menghebohkan yaitu sebuah penyakit Virus Corona. Penyakit ini telah menyebar dengan cepat ke seluruh bagian negara-negara yang ada di Dunia termasuk Indonesia. Karena penyakit Virus Corona ini, Indonesia menjadi memberlakukan suatu kebijakan yaitu Pembatasan Sosial Berskala Besar, kebijakan ini berdampak pada seluruh sector sosial-perekonomian di Indonesia. Karena kebijakan ini pula semua masyarakat Indonesia tidak bekerja dan berada di rumah saja. Hal ini lah yang menjadi pemicu utama adanya suatu tindak Kekerasan Dalam Rumah Tangga yang terjadi. Karena semua orang tidak bekerja dan berada dirumah saja, memicu adanya suatu pertikaian yang terjadi antar suami istri yang berujung pada adanya suatu tindak kekerasan yang dilakukan oleh suami kepada sang istri. Banyak faktor yang menjadi alasan mengapa kekerasan dalam rumah tangga terjadi, salah satunya karena menurunnya pendapatan ekonomi ataupun karena para suami istri mengalami stress karena keadaan ini. Diperlukan upaya yang ekstra untuk menghindari masalah kekerasan dalam rumah tangga yang terjadi dalam pandemic covid-19 in, salah satunya dengan mempertegas adanya Undang_Undang Nomor 23 Tahun 2004.

\section{Kata kunci: perlindungan hukum, virus corona, KDRT}

\section{A. Pendahuluan}

\section{Latar Belakang}

Seperti yang kita ketahui, diakhir tahun 2019 dunia sedang dilanda sebuah musibah dengan kemunculan penyakit Virus Corona yang pertama kali mengguncang negara Cina tepatnya di sebuah kota bernama Wuhan. Penyakit ini membuat sebuah pandemic yang berkelanjutan dan sudah menyebar keberbagai Negara termasuk di Indonesia. Data terakhir pada 17 juni 2020 sudah lebih dari 7,9 juta kasus telah dilaporkan di 188 negara dan wilayah hingga menyebabkan kematian lebih dari 434.000 kematian, dan lebih dari 3,96 juta orang telah pulih ${ }^{1}$.

${ }^{1}$ Wikipedia, 2020, “Penyakit Virus
Corona
https://translate.google.com/translate?u=http


Di Indonesia sendiri untuk pertanggal 17 Juni 2020, Kementerian Kesehatan Republik Indonesia telah mencatat sekiranya terdapat 41,431 orang yang telah terkonfirmasi positif mengidap penyakit virus corona, sudah lebih dari 2.270 orang yang meninggal dan 16,243 orang yang dinyatakan sembuh dari penyakit virus corona ini ${ }^{2}$.

Meningkatnya pandemik ini membuat WHO dan Pemerintah Indonesia mengeluarkan kebijakan Pembatasan Sosial Berskala Besar dimana membuat semua orang untuk berada dirumah saja dan meminimalisir kegiatan diluar rumah untuk memutus rantai penyebaran penyakit Virus Corona ini. Semua kegiatan perekonomian, pendidikan ataupun segala halnya dilakukan hanya dirumah saja. Kebijakan pembatasan sosial selama pandemic virus corona ini dianggap melanggengkan kekerasan terhadap perempuan, khususnya kekerasan dalam rumah tangga (KDRT) dan penanganan kasusnya menjadi terhambat karena adanya pandemic Virus Covid-19 ini.

Menurut Pasal 1 Angka 1 Undang-Undang Nomor 23 Tahun 2004 tentang Penghapusan Kekerasan dalam Rumah Tangga, bahwa kekerasan dalam rumah tangga adalah setiap perbuatan terhadap seseorang terutama perempuan, yang berakibat timbulnya kesengsaraan atau penderitaan secara fisik, seksual, psikologis, dan/atau penelantaran rumah tangga termasuk ancaman untuk melakukan perbuatan, pemaksaan atau perampasan kemerdekaan secara

s://en.wikipedia.org/wiki/Coronavirus_disea se_2019\&hl=id\&sl=en\&tl=id\&client=srp\&p rev=search, diakses pada tanggal 17 Juni 2020

${ }^{2}$ Riset dari website Kementerian Kesehatan Republik Indonesia, Infeksi Emerging Media Informasi Resmi Terkini Penyakit Infeksi Emerging, "Covid-19", https://covid19.kemkes.go.id/, diakses pada tanggal 17 Juni 2020 melawan hukum dalam lingkup rumah tangga ${ }^{3}$.

Di dalam kepolisian beberapa negara mengungkapkan kasus kekerasan dalam rumah tangga (KDRT) peningkatan terjadi menjadi lebih sering, lebih parah dan juga lebih membahayakan. Dilansir dari portal berita Kompas.com Marianne Hester, sosiolog dari Bristol University yang mempelajari kekerasan dalam hubungan menyebutkan bahwa pada dasarnya resiko KDRT meningkat ketika keluarga menghabiskan waktu bersama. Seperti contoh yang terjadi di China, seorang perempuan berasal dari Provinsi Anhui, China mengalami siksaan fisik dan juga psikis. Beliau kerap beradu argument dengan suaminya, hingga pada Maret lalu saat beliau sedang menggendong anaknya sang suami mulai memukul beliau dengan kursi hingga beliau tidak sadarkan diri. Contoh lainnya seperti di Inggris mengalami peningkatan kaus KDRT sebanyak 20 persen dan di Spanyol mengalami peningkatan sebanyak 18 persen ${ }^{4}$.

Menurut data Sistem Informasi Online PPPA (Simfoni-PPPA) sampai dengan 17 Juni 2020, terdapat 4.321 korban kekerasan yang terjadi terhadap perempuan ${ }^{5}$. Pada 2019 lalu, Komnas Perempuan mencatat setidaknya 11.105 kasus KDRT terjadi di Indonesia. Pembatasan sosial yang mulai diberlakukan sejak awal Maret 2020 lalu membuat kasus KDRT semakin

\footnotetext{
${ }^{3}$ Undang-Undang Nomor 23 Tahun 2004 Tentang Penghapusan Kekerasan Dalam Rumah Tangga

4 Kompas.com, 2020, “Dampak Baru Covid-19: Meningkatnya Angka KDRT di Berbagai Negara”, https://www.kompas.com/sains/read/2020/0 4/09/120300323/dampak-baru-covid-19-meningkatnya-angka-kdrt-di-berbagainegara?page $=$ all, diakses pada 17 Juni 2020

5 Kementerian Pemberdayaan

Perempuan Dan Perlindungan Anak Republik Indonesia. Sistem Informasi Online PPPA, 17 Juni 2020
} 
meningkat. Berdasarkan data lengkap dari Lembaga Bantuan Hukum (LBH) Asosiasi Perempuan Indonesia untuk Keadilan (Apik) selama 16 Maret hingga 30 Maret 2020 terdapat 59 kasus kekerasan, perkosaan, pelecehan seksual, dan online pornografi yang terjadi. Diantara kasus tersebut, 17 diantaranya adalah kasus KDRT. Menurut LBH Apik, jumlah meningkat tiga kali lipat dibandingkan sebelum diberlakukannya imbauan pembatasan sosial. Angka tersebut merupakan jumlah kasus tertinggi yang pernah dicatata oleh LBH Apik dalam kurun waktu dua pekan ${ }^{6}$.

Terlepas dari adanya Virus Corona atau tidak, karena pada dasarnya di Indonesia sendiri dari tahun ke tahun memang sudah banyak atau sudah sering terjadi tindakan KDRT yang dialami oleh perempuan itu sendiri. Kekerasan dalam rumah tangga merupakan suatu hal yang kompleks, tidak seperti halnya kejahatan yang lainnya, dimana korban dan pelaku berada dalam hubungan personal, legal, institusional, serta berimplikasi sosial. Perempuan yang dipukul oleh suaminya juga sama-sama membesarkan anak, mengerjakan pekerjaan dalam rumah, membesarkan keluarga, menghasilkan uang serta terikat secara emosional dengan pelaku kekerasan tersebut ${ }^{7}$.

Pada umumnya yang sering menjadi korban kekerasan dalam rumah tangga yaitu perempuan, hal ini terjadi

\footnotetext{
${ }^{6}$ Irwan Syambudi, 2020, "KDRT Naik Saat Corona Jadi Alarm Perlunya Kebijakan Berbasis Gender”, https://tirto.id/kdrt-naik-saat-corona-jadialarm-perlunya-kebijakan-berbasis-gendereNpk, Diakses Pada Tanggal 17 Juni 2020

7 Kumla Muhajarah, Kekerasan terhadap Perempuan Dalam rumah Tangga: Perspektif Sosio-Budaya, Hukum dan Agama, Walisongo, Universitas Islam Negeri (UIN) Walisongo Semarang, Vol: 11, No. 2, April 2016, ISSN: 0853-3857(print), ISSN: 2540-847X(online), hal. 128
}

karena budaya dan juga nilai-nilai masyarakat dibentuk oleh kekuatan patriarkal, dimana laki-laki secara kultural telah dipersilakan menjadi penentu kehidupan. Menurut Foucault laki-laki telah terbentuk menjadi pemilik kuasa yang menentukan arah wacana pengetahuan masyarakat. Kekerasan terhadap perempuan secara garis besar (pada umumnya) terjadi melalui konsep adanya control atas diri perempuan, baik terhadap pribadinya, kelembagaan, simbolik, dan materi. Dengan demikian, ketika hubungan antar jenis kelamin dikonstruk melalui hubungan dominasisubordinasi, maka perempuan berposisi sebagai pihak yang diatur oleh laki-laki. Bangunan relasi ini bekerja melalui seluruh sistem sosial tadi yang kemudian melahirkan identitas gender yang membedakan antara laki-laki dan juga perempuan ${ }^{8}$.

Dari latar belakang yang penulis paparkan diatas, maka penulis tertarik untuk membuat sebuah jurnal dengan judul "UPAYA PERLINDUNGAN HUKUM TERHADAP PEREMPUAN YANG MENGALAMI KEKERASAN DALAM RUMAH TANGGA (KDRT) DI TENGAH MASA PANDEMI COVID-19"

\section{Rumusan Masalah}

Dari latarbelakang yang penulis tulis diatas, maka dapat ditarik perumusan masalah sebagai berikut:

1. Apa faktor penyebabkan terjadinya peningkatan Kekerasan Dalam Rumah Tangga (KDRT) yang dialami oleh perempuan di tengah masa Pandemi Covid-19 ini?

2. Bagaimana perlindungan hukum terhadap perempuan yang mengalami Kekerasan Dalam

\footnotetext{
8 Kementerian Hukum Dan Hak Asasi Manusia Republik Indonesia Direktorat Jenderal Peraturan PerundangUndangan, Media Publikasi peraturan Perundang-undangan dan Informasi Hukum
} 
Rumah Tangga (KDRT) di tengah Pandemi Covid-19 ini?

\section{Tujuan Penelitian}

Sesuai dengan rumusan masalah diatas, maka tujuan penelitian ini adalah sebagai berikut:

1. Untuk mengetahui apa saja yang menjadi penyebab terjadinya peningkatan Kekerasan Dalam Rumah Tangga (KDRT) yang dialami oleh perempuan di tengah Pandemi Covid-19 ini.

2. Untuk mengetahui hal apa saja yang bisa dilakukan untuk melindungi perempuan dari adanya Kekerasan Dalam Rumah Tangga (KDRT) di tengah masa Pandemi Covid-19 ini

\section{Metode Penelitian}

Jenis penelitian hukum yang digunakan adalah penelitian hukum normatif. Yaitu penelitin yang berdasarkan disiplin ilmiah dan cara-cara kerja ilmu hukum normatif. Ilmu hukum normatif yaitu ilmu hukum yang obyeknya hukum itu sendiri. Yang dimaksud obyek hukum adalah hukum yang terutama terdiri atas kumpulan peraturan-peraturan hukum. Dalam penelitian hukum normatif digunakan pendekatan perundangundangan. Pendekatan perundangundangan akan dilakukan dengan menelaah semua Undang-Undang dan regulasi yang bersangkutan paut dengan isu hukum yang sedang ditangani.

\section{B. Hasil dan Pembahasan}

\section{Faktor Penyebab terjadinya peningkatan Kekerasan Dalam Rumah Tangga (KDRT) yang dialami oleh perempuan di tengah masa Pandemi Covid-19}

Pandemic Covid-19 memberikan dampak yang luar biasa bagi segala lini kehidupan masyarakat Indonesia. Dari semua itu, perempuan menjadi salah satu kelompok tentan yang terdampak, karena memiliki kebutuhan yang spesifik yang harus mereka penuhi. Kebutuhan spesifik ini menyangkut ketiga kodrat yang dimiliki kaum perempuan, yaitu: mengandung, melahirkan dan juga menyusui.

Jika membicarakan mengenai KDRT, kasus tersebut terjadi karena adanya perbedaan status (ketidaksetaraan posisi) antara laki-laki dan juga perempuan. Masih banyak masyarakat yang menganggap bahwa laki-laki harus memiliki sifat kuat, berani serta tanpa ampun. KDRT juga masih dipandang sebagaian masyarakat luas sebagai ranah pribadi hubungan suami istri, bukan merupakan permasalahan sosial yang bisa dicampuri.

Resiko Berbasis Gender (KBG) memanglah sangat mengancam perempuan di indonesia saat ini. Pandemic Virus Corona ini penyebab kasus KBG ini meningkat, salah satunya kasus kekerasan dalam rumah tangga (KDRT). Menurut Harkristuti Harkrisnowo dalam Aroma Elmina Martha (2003:35-37) jika dilihat dari muatannya, sebenarnya tindak kekerasan terhadap perempuan dapat dibedakan dalam berbagai bentuk, seperti diantaranya9

1) Kekerasan Fisik

$$
\begin{aligned}
& \begin{array}{l}
\text { Kekerasan fisik terhadap } \\
\text { perempuan dapat berupa } \\
\text { dorongan, } \\
\text { tendangan, } \\
\text { pukulan, }
\end{array} \text { jambakan, } \\
& \text { pukikan, bekapan, }
\end{aligned}
$$

\footnotetext{
9 Misriyani Hartati, Studi Tentang Upaya Penanganan Tindak Kekerasan Terhadap Perempuan Dan Anak (Studi Kasus Pada Pusat Pelayanan Terpadu Pemberdayaan Perempuan Dan Anak (P2TP2A) Provinsi Kalimantan Timur)), eJournal Ilmu Administrasi Negara, Fisip Universitas Mulawarman, Vol.1 No.3, September 2013, hal. 1098
} 
luka bakar, kekerasan dengan alat pemukul atau senjata tajam, dan masih banyak yang lainnya.

2) Kekerasan Seksual

Kekerasan seksual adalah setiap penyerangan yang bersifat seksual terhadap perempuan, baik telah terjadi persetubuhan atau tidak, dan tanpa memperdulikan hubungan antara pelaku dan korban.

3) Kekerasan Psikologis Pada kekerasan psikologis, sebenarnya dampak yang dirasakan lebih menyakitkan daripada kekerasan secara fisik. Bentuk tindakan ini sulit untuk dibatasi pengertiannya karena sensitivisme emosi seseorang sangat bervariasi. Identifikasi akibat yang timbul pada kekerasan psikis sulit untuk diukur.

4) Kekerasan Ekonomi Misalnya suami mengontral hak keuangan istri, memaksa istri atau melarang istri bekerja untuk memenuhi kebutuhan sehari-hari keluarga, serta tidak memebri uang belanja, memakai/menghabiskan uang istri.

Disisi lain, kasus KDRT ini tidak hanya dialami oleh mereka yang memang sudah menjadi korban, artinya Pandemi ini bisa saja menjadi pemicu sehingga menimbulkan kasus KDRT baru dilingkungan keluarga. Karena jika pada kondisi normal kegiatan keluarga lebih banyak dilakukan diluar rumah, sehingga memperkecil tingkat interaksi dan konflik yang bisa saja terjadi di dalam suatu hubungan suami-istri.

Menurut Amanda Margia Wiranata, S.Psi, M.Psi yakni seorang psikolog, memberikan beberapa faktor resiko yang menjadi penyebab KDRT meningkat selama pandemic ini. Yakni sebagai berikut ${ }^{10}$ :

a. Anggota keluarga menghabiskan lebih banyak waktu dalam area terbatas. Kemungkinan besar hal ini bisa menimbulkan konflik, yang kemudian berujung memicu terjadinya KDRT.

b. Beban kewajiban dirumah semakin meningkat sehingga menimbulkan stress.

c. Timbulnya permasalahan baru dari segi ekonomi keluarga, kesulitan mencari nafkah untuk memenuhi kebutuhan rumah tangga bisa menjadi beban tersendiri, sehingga tekanan tersebut bisa menimbulkan adanya stress hingga membuat suatu percek-cok-an dan berujung pada suatu tindakan KDRT.

d. Pembatasan swakarantina bisa dipakai oleh pelaku untuk menguasai dan mengontrol korban. Pelaku bisa megontrol dengan info yang salah tentang penyakit dan stigmatisasi pasangan.

e. Akses ke lembaga bantuan menjadi lebih sulit, sehingga membuat pelaku merasa lebih aman dalam melakukan suatu tindakan KDRT.

f. Terbatasanya kontak dengan keluarga ataupun teman korban yang dapat memberikan perlindungan maupun dukungan yang diperlukan.

\begin{tabular}{lrrr}
\hline 10 & Shafa & Nurnafisa, & 2020, \\
"Pandemi & Corona Bikin Kasus & KDRT \\
Meningkat $\quad$ Tajam, Begini & Cara \\
Mengatasinya!”, & \\
https://id.theasianparent.com/kdrt- & \\
\hline meningkat-selama-pandemi, 17 Juni & 2020
\end{tabular}


2. Perlindungan

Hukum

Terhadap Perempuan Yang

Mengalami Kekerasan Dalam

Rumah Tangga (KDRT) di tengah Pandemi Covid-19

Dari sekian banyak faktor yang memicu KDRT, kita perlu memahami pentingnya konsep kesetaraan dalam keluarga, ini adalah kunci untuk menhentikan tindak KDRT. Disetiap keluarga seharusnya sudah terbagi peran-peran yang dijalankan laki-laki dan juga perempuan, karena peran ini pada dasarnya menentukan berbagi pengambilan keputusan, serta nilai-nilai luhur termasuk nilai kesetaraan dan keadilan gender yang ditanamkan.

Lebih spesifiknya lagi terdapat beberapa upaya untuk mencegah terjadinya Kekerasan Dalam Rumah Tangga diantaranya adalah sebagai berikut:

1. Menjaga kesehatan mental dengan manajemen emosi;

2. Memperbaiki komunikasi dengan pasangan;

3. Untuk selalu melakukan quality time;

4. Membuat jadwal harian den kesepakatan tertulis dengan pasangan;

5. Cari bantuan tenaga professional.

Namun di Indonesia sendiri juga memang sudah terdapat UndangUndang Nomor 23 Tahun 2004 Tentang Penghapusan Kekerasan Dalam Rumah Tangga, didalam Undang-Undang Nomor 23 Tahun 2004 dalam Bab III, pasal (5) menyebutkan bahwa ${ }^{11}$ :

"Setiap Orang dilarang melakukan kekerasa dalam rumah tangga terhadap orang dalam lingkup rumah tangganya, dengan cara:
a.
Kekerasan fisik;
b. Kekerasan psikis;
c. Kekerasan seksual; atau

11 Undang-Undang Nomor 23 Tahun 2004 Tentang Penghapusan Kekerasan Dalam Rumah Tangga d. Penelantaran rumah
tangga."
Undang-Undang Nomor 23

Tahun 2004 tentang Penghapusan Kekerasan Dalam Rumah Tangga juga mengatur upaya perlindungan yang diberikan yakni diatur dalam Bab IV Pasal 16 sampai 38. Dalam pasal ini menyebutkan bahwa korban berhak untuk mendapatkan perlindungan dari pihak kepolisian, mendapatkan pelayanan kesehatan untuk konseling, mendapatkan relawan pendampingan, diantaranya didalam hal penyidikan, penuntutan dan tingkat pemeriksaan pegadilan, dan lain sebagainya.

Dalam pasal 38 ayat (1) menegaskan bahwa "Apabila pengadilan mengetahui bahwa pelaku telah melanggar perintah perlindungan dan diduga akan melakukan pelanggaran lebih lanjut, maka Pengadilan dapat mewajibkan pelaku untuk membuat pernyataan tertulis yang isinya kesanggupan untuk mematuhi perintah perlindungan." Ayat (2): “Apabila pelaku tetap tidak mengindahkan surat pernyataan tertulis tersebut sebagaimana dimaksud ayat (1) pengadilan dapat menahan pelaku paling lama 30 hari." Lebih lanjut ayat (3) menyatakan: "Penahanan sebagaimana dimaksud ayat (2) disertai dengan surat perintah penahanan". Selain itu ketentuan pidananya juga sangat jelas diterangkan dalam Undang-Undang Nomor 23 tahun 2004 ini dalam pasal 44-53, seperti pada Pasal 44 ayat (2) menyatakan bahwa: "setiap orang yang melakukan perbuatan kekerasan fisik dalam lingkup rumah tangga, dan mengakibatkan korban mendapat jatuh sakit atau luka berat dipidana dengan pidana paling lama 10 (sepuluh) tahun atau denda paling banyak Rp. 30.000.000,00 (tiga puluh juta rupiah)."

Di dalam Undang-Undang tersebut sebenarnya sudah sangat dijelaskan perlindungan yang diterima oleh para korban jika menerima sebuah 
tindakan Kekerasan Dalam Rumah Tangga, tetapi pada dasarnya masih banyak pelaku yang tidak mengindahkan atau memperdulikan atas UndangUndang yang ada tersebut dan para korban cenderung untuk tidak melaporkan sebuah kekerasan yang terjadi pada dirinya sendiri dengan alasan sebagi untuk mempertahankan suatu hubungan rumah tangga ataupun untuk menjaga sebuah kehormatan dari suaminya sendiri.

\section{Penutup}

\section{Simpulan}

1. Faktor penyebab KDRT meningkat selama pandemic ini. Yakni sebagai berikut:
a. Anggota keluarga menghabiskan lebih banyak waktu dalam area terbatas
b. Beban kewajiban dirumah semakin meningkat sehingga menimbulkan stress
c. Timbulnya permasalahan baru dari segi ekonomi keluarga
d. Pembatasan swakarantina bisa dipakai oleh pelaku untuk menguasai dan mengontrol korban
e. Akses ke lembaga bantuan menjadi lebih sulit
f. Terbatasanya kontak dengan keluarga ataupun teman korban

2. Perlindungan hukum terhadap perempuan yang mengalami KDRT diatur oleh Undang-Undang Nomor 23 Tahun 2004 tentang Penghapusan Kekerasan Dalam Rumah Tangga yakni diatur dalam Bab IV Pasal 16 sampai 38. Dalam pasal ini menyebutkan bahwa korban berhak untuk mendapatkan perlindungan dari pihak kepolisian, mendapatkan pelayanan kesehatan untuk konseling, mendapatkan relawan pendampingan, diantaranya didalam hal penyidikan, penuntutan dan tingkat pemeriksaan pegadilan, dan lain sebagainya.

\section{Saran}

$\begin{array}{cll} & \text { Secara tegas Undang_Undang } \\ \text { ini telah menyebutkan upaya }\end{array}$ Perlindungan Hukum yang diterima, Hak-Hak Korban, Kewajiban Pemerintah berikut juga dengan Masyarakat serta yang lainnya. tetapi memang banyak yang mengabaikan tentang berlakunya Undang-Undang ini, sehingga memang sangat diperlukan untuk keterlibatan Pemerintah dalam upaya mengdeklarasikan tentang Undang-Undang ini agar masyarakat Indonesia semakin mengerti tentang artinya menjaga keutuhan dalam rumah tangganya sekaligus untuk meminimalisir terjadinya kekerasan dalam rumah tangga.

\section{DAFTAR PUSTAKA}

\section{JURNAL}

Muhajarah, Kumla Kekerasan terhadap Perempuan Dalam rumah Tangga: Perspektif SosioBudaya, Hukum dan Agama, Walisongo, Universitas Islam Negeri (UIN) Walisongo Semarang, Vol: 11, No. 2, April 2016, ISSN: 0853-3857(print), ISSN: 2540-847X(online)

Misriyani Hartati, Studi Tentang Upaya Penanganan Tindak Kekerasan Terhadap Perempuan Dan Anak (Studi Kasus Pada Pusat Pelayanan Terpadu Pemberdayaan Perempuan Dan Anak (P2TP2A) Provinsi Kalimantan Timur)), eJournal Ilmu Administrasi Negara, Fisip Universitas Mulawarman, Vol.1 No.3, September 2013

\section{PERATURAN \\ UNDANGAN}

PERUNDANG-

Undang-Undang Nomor 23 Tahun 2004 tentang Penghapusan Kekerasan dalam Rumah Tangga, Lembaran Negara Republik Indonesia Tahun 2004 Nomor 95, Tambahan Lembaran 


\section{Negara Republik Indonesia \\ Nomor 4429 \\ INTERNET}

Wikipedia, 2020, "Penyakit Virus Corona 2019", https://translate.google.com/tran slate? $\mathrm{u}=\mathrm{https}: / /$ en.wikipedia.org/ wiki/Coronavirus disease 2019 $\underline{\text { hl }}=\mathrm{id} \& \mathrm{sl}=\mathrm{en} \& \mathrm{tl}=\mathrm{id} \& \mathrm{client}=\mathrm{sr}$ p\&prev=search, diakses pada tanggal 17 Juni 2020

Riset dari website Kementerian Kesehatan Republik Indonesia, Infeksi Emerging Media Informasi Resmi Terkini Penyakit Infeksi Emerging, "Covid-19",

https://covid19.kemkes.go.id/, diakses pada tanggal 17 Juni 2020

Kompas.com, 2020, "Dampak Baru Covid-19: Meningkatnya Angka KDRT di Berbagai Negara", https://www.kompas.com/sains/ read/2020/04/09/120300323/da mpak-baru-covid-19-meningkatnya-angka-kdrt-diberbagai-negara?page $=$ all, diakses pada 17 Juni 2020

Kementerian Pemberdayaan Perempuan Dan Perlindungan Anak Republik Indonesia. Sistem Informasi Online PPPA, 17 Juni 2020

Kementerian Hukum Dan Hak Asasi Manusia Republik Indonesia Direktorat Jenderal Peraturan Perundang-Undangan, Media Publikasi peraturan Perundangundangan dan Informasi Hukum

Shafa Nurnafisa, 2020, "Pandemi Corona Bikin Kasus KDRT Meningkat Tajam, Begini Cara Mengatasinya!",

https://id.theasianparent.com/kd rt-meningkat-selama-pandemi, 17 Juni 2020 